In North Africa, Tunis is also infested in a very high degree. Vidal declares that animals whose liver is completely free of the parasite are very rare.

In Australia echinococci are almost as common as in Iceland. In British India, where dogs are very common, 70 per cent. of the ox tribe suffer from echinococcosis of the liver. In the Argentine Republic, particularly in the province of Buenos Aires, hydatid cysts of the liver and lung are very frequent- 40 per cent. of the ox tribe, 60 per cent. of the sheep, and 70 per cent. of the pigs, suffering from them. On the other hand, they are rare in Brazil, Chili, and Peru. They are also very rare in the United States.

\title{
(C.) PROPHYLAXIS.
}

If curative treatment of echinococcosis is impossible in the domestic animals, prophylaxis is very important. It is necessary to prevent dogs and cats contracting the tænia echinococcus. Dogs which frequent abattoirs or private slaughter-houses are most exposed to infestation. The admission of dogs to slaughter-houses should therefore be forbidden. Dogs should never be fed with viscera containing, or suspected of containing, hydatids. All viscera infested with echinococci should be seized and burned, because we now know that the scolices are endowed with very much greater powers of resistance than was formerly believed. Finally, it is desirable periodically to administer to dogs a course of anthelminthic medicine to rid them of the tænia echinococci which they may be harbouring in the intestine. The prophylactic measures must be applied to the carnivora. It is useless to attempt to prevent herbivora and swine from swallowing the embryos of the trenia. This is an absolute impossibility. If applied to the dog these measures would be highly efficacious, and it is desirable that they should be generally carried out, for it must not be forgotten that in man echinococcosis is a serious disease, the frequency of which stands in direct relationship to its occurrence in animals, and that in protecting the latter from the disease we are protecting ourselves.

\section{COMPENSATION PAID FOR THE SEIZURE OF MEAT AND THE SLAUGHTER OF ANIMALS ON ACCOUNT OF TUBERCULOSIS IN FRANCE ${ }^{1}$}

\author{
By H. Martel, D.Sc., Chief of Veterinary Service of Paris and \\ of the Department of the Seine.
}

IN France, since I898, the State has granted compensation to the owners of tuberculous animals. The indemnity in the case of meat seizure and animal slaughter on account of tuberculosis is provided in accordance with articles 36 and 52 of the law of the 2 Ist June I 898 . Article 36 of the law in the rural code provides for slaughter, upon the order of the Mayor, of animals of the bovine species duly certified to be affected with tuberculosis; article 52 of the same law

1 Translated from "L'Hygiène de la viande et du lait," July 1907, by John F. J. Sykes, M.D., D.Sc., M.O.H., St. Pancras, London. 
grants indemnity in the case of the seizure of meat on account of tuberculosis to owners who have conformed to the requirements of the laws and rules of the Sanitary Police, the amount of the indemnity to be regulated in accordance with the proportions established by the financial law of 1898 .

The financial law of the $13^{\text {th }}$ April 1898 contains in article 81 the following provisions:-

In the case of meat seized on account of tuberculosis, compensation is granted to owners who have conformed to the laws and regulations of the Sanitary Police.

The amount of the indemnity shall be equal to one-half of the value of the meatseized in the case of generalised tuberculosis, and to three-fourths of the value in the case of localised tuberculosis.

The compensation shall be the total value of an animal slaughtered by order of the Admınistration if it is found upon slaughtering that the animal was not affected with tuberculosis, and in this case the value of the meat sold by the owner, under the control of the Mayor, shall be deducted from the compensation.

The State granted during the first year of enforcement of compensation a sum equal to 103,924 francs.

The Departments which received the most indemnity were: Nord ( I 5,833 francs), Basses-Pyrénées (9769 francs), Gers (329I francs), Maine-et-Loire (3670 francs), Vendée (34I9 francs).

During the year I 899 (Ist January to 30th May) the State paid to the owners of tuberculous animals the sum of 125,785 francs.

The number of animals affected with localised tuberculosis was 224 in 1898 and 265 in 1899 (the first five months of the year); 67 I and 867 cases of generalised tuberculosis. The average indemnity allowed fell from about I 22 francs (I 898) to IO2 francs (I899) for localised tuberculosis; it varied little (I 2 and I I 3 francs) for cases of generalised tuberculosis. Finally, I 62 francs for five animals were paid in cases of errors of diagnosis-say 232 francs per head.

The financial law of the 3oth May I 899 (article 4I) modifies completely the basis of the valuation for compensation in cases of seizure of meat or slaughter on account of tuberculosis. It runs as follows :-

Article $8 \mathbf{r}$ of the firancial law of the 13 th April 1898 , granting indemnities in the cases of selzure of meat or the slaughter of animals on account of tuberculosis, is superseded by the following provisions:-

In the case of the seizure of meat or slaughter of animals on account of tuberculosis, indemnities are granted to owners who have conformed to the laws and rules of the Sanitary Police.

These indemnities shall be regulated in the following manner:--

(I) To the third of the value of the animal at the moment of slaughter when the tuberculosis is generalised;

(2) To the total value of the animal slaughtered by administrative order if it is found upon slaughter that the animal was not affected with tuberculosis.

In all cases the value of the meat and of the strippings sold by the proprietor, under the control of the Mayor, shall be deducted from the indemnity, provided that this indemnity shall not be more that 200 francs for the third of the value and $45^{\circ}$ francs for three-fourths of the value.

The Ministerial instructions of the 3 rd August I 899 , in remarking that the basis of the valuation of animals for which indemnities are 
granted have been completely modified, do not say that the animal to be slaughtered, affected with or suspected of tuberculosis, ought always to be regarded as an animal intended for butcher's meat; but the Ministerial letters addressed to the Prefects of l'Herault and of Seine-et-Marne established the fact that the estimated value is that of an animal intended for butcher's meat, except in the case where an error of diagnosis has been made.

It is said that the indemnities granted on the basis and proportions of the law of I 898 only presented an insignificant advantage, especially if one took into account the prejudice caused to the owner demanding the indemnity (slaughter under special surveillance, suspicion by the public of the shed declared infected, ridicule of the tax for compensation, etc.). It has also been said that owners had an interest in concealing sources of tuberculous infection.

With the application of the régime of 1899 the results obtained have not been better.

The amount of the indemnities has increased each year.

\begin{tabular}{|c|c|c|c|c|c|c|}
\hline & \multirow[b]{2}{*}{ Years. } & & \multirow[b]{2}{*}{$\begin{array}{l}\text { Total Sums } \\
\text { Paid. }\end{array}$} & \multicolumn{3}{|c|}{ Sums Paid. } \\
\hline & & & & $\begin{array}{c}\text { Cases of } \\
\text { Localised } \\
\text { Tuberculosis. }\end{array}$ & $\begin{array}{c}\text { Cases of } \\
\text { Generalised } \\
\text { Tuberculosis. }\end{array}$ & $\begin{array}{l}\text { Errors of } \\
\text { Diagnosis. }\end{array}$ \\
\hline 1899 & . & . & $\begin{array}{c}F r . \\
197,176\end{array}$ & $\begin{array}{c}F r \\
87,864\end{array}$ & $\begin{array}{c}F r . \\
102,670\end{array}$ & $\begin{array}{l}F r . \\
9, \text { I I I }\end{array}$ \\
\hline I900 & . & . & 478,201 & 287,9 工 5 & $\mathbf{I} 8 \mathbf{I}, 795$ & I 3,854 \\
\hline I90I & . & . & 546,897 & 352,753 & $\mathrm{I} 88,6 \mathrm{IO}$ & 8,665 \\
\hline 1902 & . & . & 633,087 & $3^{8} 7,985$ & 236,173 & $13,3^{8} 3$ \\
\hline 1903 & . & . & 682,556 & $406,33^{8}$ & $268,55^{2}$ & $1 \mathrm{I}, 3 \circ 2$ \\
\hline 1904 & . & . & 849,070 & 502,059 & 340,258 & 9,522 \\
\hline 1905 & . & . & $899, \circ 39$ & 5 I $8,9 \circ 8$ & 373,911 & IO, $3^{8} \mathrm{I}$ \\
\hline
\end{tabular}

It must be observed that the financial law of 1899 made certain modifications. Article 82 of the law of the 30 th March 1902 provides. that :-

The indemnities provided by the financial law of the 3 oth May 1899 will be allocated to the owner of every animal slaughtered in a public slaughterhouse, the meat of which shall have been totally or partially seized on account of tuberculosis, under the direction of the veterinary charged with the inspection of the slaughter-house. Previous declaration not required.

For the financial law of the 30th December I903 (article 26) is substituted article 82 of the law of the 30 th March 1902 by the following :-

The indemnities provided by the financial law of the 3oth May 1899 . . . shall be allocated :-

(I) To owners who shall conform to the laws and regulations of the Sanitary Police ;

- (2) To owners who have, either directly or through intermediaries, sent their animals into a public slaughter-house or into a private slaughter-house 
under the permanent surveillance of a veterinary appointed by the Prefect of the Department, and who are prejudiced by the seizure;

(3) To owners who have sent their animals into any place for slaughter if they have requisitioned, before slaughtering, the visit of the veterinary who has made the seizure in his capacity of Sanitary Veterinarian appointed by the Prefect of the Department.

In addition the law of the $17^{\text {th }}$ April 1906, which fixes the general budget of expenses and receipts during 1906, by article 62 modifies the last lines of article $4 \mathrm{I}$ of the law of the 30 th May 1899 in the following manner :-

In all cases, except that of total seizure, the value of the meat and strippings sold by the owner, under the control of the Mayor, shall be deducted from the indemnity.

Article 63 of the same law modifies the last paragraph of article 26 of the financial law of the 3 oth October 1903 in the following manner :-

(3) . . To owners who have sent their animals into any place for slaughter if they have requisitioned, before slaughtering, the visit of a veterinary appointed by a Prefectorial Administration.

The law of 1899 has relieved some of the inconveniences of the law of 1898 . It has permitted the discovery of a larger number of tuberculous centres. These have become officially known in greater and greater numbers, but the struggle against tuberculosis by the application of legal measures has remained inoperative, and, under these conditions, promises to remain for long inefficacious in France.

The special object of the law of I 899 is the early declaration of tuberculosis, and the indemnity or compensation may be regarded as an inducement of declaration and of the discovery of centres of infection. Nevertheless, from this point of view, the results obtained are disputable. The amount of indemnity in the cases of localised tuberculosis is such that the owner of a tuberculous animal is only entitled to the indemnity if the value of the portion seized is more than one-fourth of the estimated value of the animal, and this latter cannot be more than 450 francs. In fact, the indemnity is in exact proportion to the importance of the seizure.

The relative value of the factors in calculating the amount of the indemnity in each case presents great difficulties. In addition, the control of the operations carried on is difficult; above all, under the slight surveillance exercised by the Departmental Veterinarians of certain areas. Apart from the idea of fraud, the possibility of which is beyond doubt, it may be conceived how difficult it is to form the exact valuation according to the weight of the standing animal when slaughtering is carried out in any place of slaughter far from exact means of weighing, and under conditions which render the work of the veterinarian difficult and delicate.

In estimating the amount to be deducted for the sale of the meat and strippings other serious inconveniences are met. Butchers offer a ludicrous price for meat sold under such conditions, because they know well that in France it is impossible to find the display of lowquality butchers' meat officially recognised, and a reasonable chance given to the sale of meat having incontestably nourishing properties although partly disqualified. 
The total amount of indemnity or compensation granted, that is to say, the cost of inducement to notify or make declarations, weighs heavily upon our finances, and without profiting the struggle against tuberculosis.

The indemnity granted is specially high in the case of localised tuberculosis. It increased with the regime of 1899 . Under the law of 1898 it averaged I 2 I francs per animal. Since 1899 it has reached successively I46, I 56, I 39, I 24, I 22, I 36, and I 33 francs. ${ }^{1}$

$\begin{array}{cccccccccc}\begin{array}{l}\text { Years } \\ \text { Amount of }\end{array} & 1898 & 1899 & 1899 & 1900 & 1901 & 1902 & 1903 & 1904 & 1905 \\ \text { indemnity } & 121 \cdot 97 & 102 \cdot 02 & 146 \cdot 68 & 156 \cdot 47 & 139 \cdot 26 & 124 \cdot 35 & 122 \cdot 95 & 136 \cdot 12 & 133.60\end{array}$

It must also be stated that the Administrative Department of Agriculture has little by little raised the mean amount recovered from the sale of meat and strippings.

$\begin{array}{lccccccc}\text { Years } & 1899 & 1900 & 1901 & 1902 & 1903 & 1904 & 1905 \\ \text { Meat and strippings } & 68 \cdot 22 & 66 \cdot 52 & 59 \cdot 61 & 72 \cdot 75 & 88 \cdot 29 & 90 \cdot 09 & 92 \cdot 64\end{array}$

But as the average value of the animals has increased, the result has been that the average amount of the indemnity has remained relatively high.

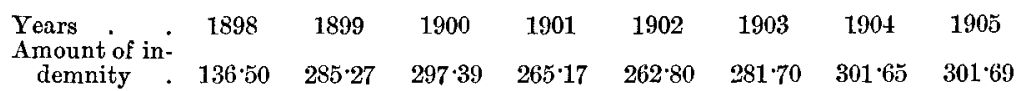

The number of cases of localised tuberculosis have increased, especially during the last few years (265 in 1899 against 1840 in I900); the increase has been regular but less rapid than the cases of generalised tuberculosis.

\begin{tabular}{|c|c|c|c|c|c|c|c|c|c|}
\hline \multicolumn{8}{|c|}{ Years. } & \multirow{2}{*}{$\begin{array}{c}\begin{array}{c}\text { Cases of } \\
\text { Localised } \\
\text { Tuberculosis. }\end{array} \\
224\end{array}$} & \multirow{2}{*}{$\begin{array}{c}\begin{array}{c}\text { Cases of } \\
\text { Generalised } \\
\text { Tuterculosis. }\end{array} \\
67 \mathbf{I}\end{array}$} \\
\hline 1898 & - & . & . & - & . & . & - & & \\
\hline I 899 & . & . & . & . & . & . & . & 265 & 867 \\
\hline I 899 & . & . & . & . & . & . & . & 599 & $\mathrm{I}, \mathrm{I} 89$ \\
\hline 1900 & . & . & . & - & . & . & . & $\mathrm{I}, 840$ & 2,235 \\
\hline Igo I & . & . & . & . & . & . & . & 2,533 & 2,547 \\
\hline 1902 & . & . & . & - & - & - & - & $3, \mathrm{I} 20$ & 3,373 \\
\hline $19 \circ 3$ & - & . & • & . & - & - & . & $3,3 \circ 4$ & 3,371 \\
\hline I904 & . & - & • & . & . & - & - & 3.687 & $4,68 \mathrm{I}$ \\
\hline 1905 & . & . & . & . & . & . & . & 3,884 & 5,053 \\
\hline
\end{tabular}

As to the mean value ${ }^{2}$ of the sale of meat and strippings in cases of generalised tuberculosis one obtains the following figures:-

\begin{tabular}{|c|c|c|c|c|c|c|}
\hline Years Value of the sale of meat & 1899 & 1900 & 1901 & 1902 & 1903 & 1904 \\
\hline
\end{tabular}

1 The average is much less when the inspection of meat is carried out by a well-organised sanitary service. In Paris it is only 131.80 francs per animal (an average of twenty-five cases taken haphazard in the course of the year 1907). The seizures of meat vary in weight from 50 to 100 kilogrammes.

2 The dearness of hides during the winter of 1906.07 might have diminished the State contribution by 40 francs per head of tuberculous animal ("Statistics of the Vincennes Slaughterhouse ") if the law of the 17 th April 1906 had not intervener. 
It is on record that a gradual diminution of the mean amount of indemnity granted has taken place :-

$\begin{array}{cccccccccc}\begin{array}{l}\text { Years } \\ \begin{array}{c}\text { Amount of } \\ \text { indemnity }\end{array}\end{array} & 111 \cdot 49 & 1899 & 1899 & 1900 & 1901 & 1902 & 1903 & 1904 & 1905 \\ \begin{array}{c}\text { Mean value } \\ \text { of animals }\end{array} & -- & 227 \cdot 51 & 284 \cdot 23 & 272 & 275 \cdot 20 & 258 \cdot 42 & 273 \cdot 72 & 279 \cdot 66 & 285 \cdot 03\end{array}$

Finally, as far as concerns the amount paid for errors of diagnosis, the following figures appear :-

$\begin{array}{lcccccccc}\text { Years } & . & 1899 & 1900 & 1901 & 1902 & 1903 & 1904 & 1905 \\ \text { Number of animals } & : & 36 & 51 & 36 & 55 & 43 & 33 & 32 \\ \text { Mean value } & : & 253 & 271 & 240 & 243 & 262 & 288 & 324 \\ \text { Mean value of the sale of } & & & & & & & \\ \text { meat and strippings } & \cdot & 68 \cdot 50 & 69 \cdot 90 & 87 & 80 \cdot 90 & 84 \cdot 50 & 86 \cdot 90 & 9870 \\ \text { Mean indemnity : } & - & 18450 & 166 \cdot 60 & 153 \cdot 60 & 162 \cdot 30 & 172 \cdot 20 & 204 \cdot 60 & 225 \cdot 60\end{array}$

The detailed statistics of indemnities granted for the slaughter of animals and for meat seized as part of tuberculous animals would make one believe that tuberculosis is extending in certain Departments with hopeless rapidity, the result of a defective prophylaxis.

It is certain that some Departments are affected more than others by tuberculosis, and that certain strains of animals pay a very heavy tribute to the disease, but that which strikes one most in the official statistics is the exorbitant indemnity granted each year to certain Departments, notably to those of Lot-et-Garonne and BassesPyrénées.

In I903, in order to remedy this grave situation, the Ministers of Agriculture and of Finance laid before the Chamber a project considerably modifying the conditions of compensation. This is the text of the Government's project :-

Article $4 \mathrm{I}$ of the financial law of the 3 oth May $\mathrm{x} 899$ and article 82 of the financial law of the 3 Ist March 1902 are replaced by the following provisions:-

In cases of seizure of meat on account of tuberculosis indemnities are granted-

(I) To owners who have conformed to the laws and regulations of the Sanitary Police;

(2) To owners who have sent their animals directly into a public slaughterhouse, or into a private slaughter-house placed under the control of a Veterinarian approved by the Prefect of the Department.

These indemnities are restricted to a third of the value of the animal at the moment of slaughter, and they must not exceed 200 francs for each beast.

The product of the sale of meat and strippings belongs to the owner, but if it is more than two-thirds of the value of the animal, the State indemnity is reduced by the amount of the excess.

In the case of slaughter by administrative order, on account of tuberculosis, of an animal found after slaughter not to be tuberculous, an indemnity equal to the total value of the animal is granted, from which is deducted the amount obtained from the sale of the meat and strippings.

This manner of dealing with the problem of compensation has an indisputable superiority over the regulations under the law of I 899.

Amongst other advantages the project of the Government avoids certain difficulties of application, since it renders it unnecessary to establish a distinction between cases of generalised and localised tuberculosis. It directly interests the owner in the sale of the meat and strippings of tuberculous animals. It grants a larger indemnity 
to the owner of tuberculous animals, and so conduces to early declaration. Besides, in requiring that public and private slaughter-houses and slaughtering places should be regularly supervised by a veterinarian, it tends to give a remarkable impulse to the inspection of meat, the extension of which is so much pressed by hygienists. Lastly, the expression "Approved by the Prefect," used to designate the veterinary inspector, tends to the recognition of the latter as a municipal officer, and as also connected with the Central Authority.

Although the projected law of the Government does not mention any rules which should govern the value of living animals, there is reason to believe that the indemnity should be based upon the value of the animal regarded as intended for butcher's meat. As regards the obligation which is imposed upon owners demanding compensation, and which consists in requiring them to send their animals directly into a supervised slaughter-house, it must doubtless be understood that the Government thereby desires, above all, not to be subjected to granting indemnities to those who make a business of submitting tuberculous animals to successive sales, and making an income by obtaining compensation. In this matter one can only approve of the authors of a law intenced to limit fraud and to safeguard the interests of the State.

There only remains one question, especially difficult of solution, that of the importance of the amount of indemnity to be granted in each case.

If by seizure on account of tuberculosis one understands the withdrawal from consumption of a part of the carcase of the slaughtered animal, the danger to the finances of the State is not very great; but the same will not apply if, in future, indemnities are granted for all cases of tuberculosis, whatever may be the degree of the malady certified.

One knows that cases of localised tuberculosis are much the most numerous. If an indemnity be granted in every case the amounts to be paid will become very considerable. They will be the more so inasmuch as the amount of the sale of the meat and the strippings will rarely be higher than two-thirds of the value of the animal.

The proposed law of the Government was adopted by the Chamber of Deputies, increasing the indemnity to be granted to half the value of the animal, and fixing the maximum indemnity at 300 francs in each case (16th June I904).

According to the statement of $\mathrm{M}$. de la Batut, of the Commission of Agriculture, the indemnity to be paid may be inversely proportional to the quantity of meat seized, and in certain cases persons interested may even recoup the total value of their animals.

By many Members of Parliament the indemnity for the slaughter or seizure of the meat of tuberculous animals is regarded as in some way an assistance given to agriculture more than as a means of helping the struggle against bovine tuberculosis. The time has perhaps come to say how dangerous such conceptions may be, and to show that the results obtainable, even if the project of the Government were acceptable, can only be of doubtful efficacy.

At the commencement of the application of the decree of the 6th October I9O4 it was believed that testing with tuberculin would become general in areas declared infected. 
As a matter of fact, in the suburbs and in Paris at the commencement of the application of the decree the greater part of the owners of cowsheds had recourse to testing with tuberculin. The results obtained frightened the purveyors of milk; when they found out the enormous proportion of cases of tuberculosis disclosed by tuberculin they partly abandoned the usage of this valuable test. The facilities that they have of selling their fatted animals directly to the public slaughter-house or upon the markets destined for the slaughter-house do not tempt them to have recourse to the use of tuberculin.

As far as concerns local exploitation the problem presents itself under other conditions. The declaration of infection has an advantage in hindering the commerce in animals, these not being always destined for slaughter.

The actual situation may be summed up in saying that the number of declarations of tuberculous centres increases from year to year, but that, on the other hand, the number of tuberculous animals does not diminish under the application of the law for the payment of indemnities. Few owners have the necessary perseverance to complete the difficult work of eliminating the disease from an infected herd, especially when agricultural work is pressing.

Besides, one knows that Belgium, endowed with a well-organised sanitary service, has only obtained mediocre results up to the present, the prophylaxis of tuberculosis being equally based upon indemnification.

It must be added that Belgium and France are almost the only countries where indemnification is granted with much facility and upon a large scale. Generally speaking, other States reserve the payment of an indemnity for cases of slaughter by administrative order; the amounts voted are principally utilised with a view to facilitate free prophylaxis by the employment of tuberculin, by the examination for open tuberculosis, etc. In Germany the opinion is reasonably held that it is the duty of interested persons, breeders or butchers, to defend themselves against the risks of seizure at the public slaughter-house. Mutual insurance advantageously takes the place of indemnification by the State. This last solution is perhaps one of the best that can be found to the problem.

We have already seer that the projects laid down by the Ministers of Agriculture and of Finance, of the Ioth March 1903, presented real immediate advantages over the law of the 3oth May I899. It remains to ascertain if, in condemning entirely any system which rests upon the indemnification largely given to all owners of tuberculous animals, there would not be a real advantage, failing any other solution, in returning to the valuation of the indemnity in accordance with the importance of the parts seized on account of tuberculosis.

Every time that the sanitary service is called upon to value a standing animal, above all in the country, the butcher, who never overlooks the situation in which his vendor is placed, never fails to profit by it. He almost always offers an absurd price for the animals. Besides, as we have already said, valuing a living animal is always difficult; the use of the weighing machine after slaughter is less liable to error. 
Some examples are perhaps useful in order to understand the process of valuing and the inconvenience attached thereto, if the proposed law voted by the Chamber of IgO4 were definitely adopted.

Suppose that one has a cow of the value of 300 francs, and that at the slaughter-house the Inspector seizes 150 francs' worth of meat (partial seizure), the indemnity to be paid by the State would be I 50 francs.

In practice, cases will present themselves with different complications. The butcher will offer a less price for the animal. He will pay, for instance, 250 francs for it. By this the proprietor will lose 25 francs. Sometimes one will find an exaggerated estimate of value, reaching 400 francs, for example. The State will have to pay 200 francs; one may be sure that the part represented by the amount received for meat and strippings will rarely exceed 200 francs. ${ }^{1}$

In theory, the State ought only to pay half the excess after reduction if the amount of the sale of the meat and strippings left with the interested person is more than $25^{\circ}$ francs. Thus it will be in slaughter-houses superintended by a regular organised service. $^{2}$

But in the rural parts of the provinces, far from all surveillance, irregular values of living animals may occur, and the State may pay 200 francs and more for the seizure of 30 or 40 kilogrammes of meat.

In certain cases the differences will be less under the proposed Government law. One cannot say that it will always be so, especially in cases of localised tuberculosis.

In the face of such inconveniences, of which the existence has been recognised in the application of the law of 1899 , and of which the alleviation promises to be insufficient under any system based upon the fixing of the indemnity upon the value of the living animal, it seems necessary to endeavour to return to the principle of indemnification according to the value of the parts seized. It is possible that

${ }^{1}$ Up to the present day the average price of the meat and the strippings has never reached 100 francs, even in the case of localised tuberculosis. On the other hand, it reaches 430 francs for animals slaughtered in Paris slaughter-houses, and 235 francs for animals slaughtered in the Vincennes slaughter-houses.

2 Here are some figures taken haphazard in the course of the last few days from the demands of indemnities which have been presented and of which the articles have reached us. They were the result of seizures of meat made in the public slaughter-houses of the Seine Department:-

\begin{tabular}{|c|c|c|c|c|c|c|c|}
\hline \multicolumn{5}{|c|}{ Localised Tuberculosis. } & \multicolumn{3}{|c|}{ Generalised Tuberculosis. } \\
\hline \multirow{2}{*}{$\begin{array}{c}\text { Weight of } \\
\text { Meat } \\
\text { Seized. }\end{array}$} & \multirow{2}{*}{$\begin{array}{c}\text { Value } \\
\text { of the } \\
\text { Animal. }\end{array}$} & \multirow{2}{*}{$\begin{array}{l}\text { Product } \\
\text { of the } \\
\text { Meat and } \\
\text { Strippings. }\end{array}$} & \multicolumn{2}{|c|}{ Indemnity. } & \multirow{2}{*}{$\begin{array}{c}\text { Value } \\
\text { of the } \\
\text { Animal. }\end{array}$} & \multicolumn{2}{|c|}{ Indemnity. } \\
\hline & & & $\begin{array}{c}\text { Law of } \\
1899-1906\end{array}$ & $\begin{array}{l}\text { Vote of the } \\
\text { Chamber } \\
\text { (1904). }\end{array}$ & & $\begin{array}{c}\text { Law of } \\
1899-1906 .\end{array}$ & $\begin{array}{c}\text { Vote of the } \\
\text { Chamber } \\
\text { (1904). }\end{array}$ \\
\hline $\begin{array}{c}\text { Kil. } \\
97 \\
67 \\
72 \\
80 \\
-\end{array}$ & $\begin{array}{l}F r . \\
550 \\
800 \\
590 \\
580 \\
-\end{array}$ & $\begin{array}{l}F r . \\
416 \\
711 \\
489 \\
400 \\
-\end{array}$ & $\begin{array}{l}\text { Fr. } \\
- \\
\overline{-} \\
\overline{35}\end{array}$ & $\begin{array}{r}F r . \\
134 \\
89 \\
181 \\
180 \\
-\end{array}$ & $\begin{array}{l}F r . \\
120 \\
105 \\
230 \\
535 \\
470\end{array}$ & $\begin{array}{c}F r . \\
40 \\
35 \\
74 \cdot 30 \\
178 \cdot 30 \\
156 \cdot 60\end{array}$ & $\begin{array}{l}F r . \\
60 \\
52 \cdot 50 \\
115 \\
267 \cdot 50 \\
235\end{array}$ \\
\hline
\end{tabular}


such a method would produce a diminution of the declaration of tuberculous centres. ${ }^{1}$

The proposed law, deposited by the Senator, M. Darbot, in I905, tends to base indemnification upon this last principle.

With the object of avoiding too heavy and useless expenses by the State, it seems necessary to take this view, and to demand that indemnity in all cases of tuberculosis, whatever the form, should be calculated according to the value of the parts seized (this being estimated as wholesome meat), having regard to the quality and the category. Besides, in order to avoid fraud in connection with tuberculous beasts arrived at the last stage of the disease, it is desirable to accord a very restricted indemnity or not to give any at all in these special cases.

The indemnity might be fixed in the following manner:-

Half the value of the parts seized whatever may be the form of tuberculosis.

The whole value of an animal slaughtered by administrative order if it be found upon slaughtering that the animal was not affected with tuberculosis.

No indemnity should be granted for tuberculous animals exhausted by the disease.

The indemnity in each case should not be higher than roo francs.

The amount of the sale of the meat and strippings should belong by right to the owner.

The indemnity should only be granted to owners of animals sold for direct slaughtering in an abattoir supervised by a veterinary surgeon approved by the Prefect.

It is evident that it is desirable to modify in a complete manner the basis of the struggle against tuberculosis.

The State should only grant indemnities to those who undertake to struggle against tuberculosis, and under certain defined conditions. ${ }^{2}$

The mean figures arrived at after the analyses of the 112 cases as they have been presented give the following results :-

\begin{tabular}{|c|c|c|c|}
\hline & \multirow{2}{*}{$\begin{array}{c}\text { Regime } \\
1899-1906 .\end{array}$} & \multicolumn{2}{|c|}{ Indemnities. } \\
\hline & & $\begin{array}{c}\text { Project } \\
\text { of the } \\
\text { Government. }\end{array}$ & $\begin{array}{c}\text { Vote of the } \\
\text { Chamber } \\
\text { (1904). }\end{array}$ \\
\hline Abattoir of the Seine (including Paris). & Fr. & Fr. & Fr. \\
\hline $\begin{array}{l}23 \text { cases of generalised tuberculosis } \\
24 \text { cases of localised tuberculosis (seizure of } 50 \text { to } 100\end{array}$ & $109 \cdot 38$ & $109 \cdot 38$ & $165 \cdot 68$ \\
\hline kilogrammes of meat). & $13 \cdot 73$ & $117 \cdot 13$ & 119 \\
\hline $\begin{array}{c}\text { Abattoir Vincennes (animals of mediocre } \\
\text { quality). }\end{array}$ & & & \\
\hline $\begin{array}{l}30 \text { cases of generalised tuberculosis } \\
25 \text { cases of localised tuberculosis (seizure of } 5 \text { to } 10\end{array}$ & $51 \cdot 72$ & $51 \cdot 72$ & $77 \cdot 12$ \\
\hline kilogrammes of meat). . . . . . & - & $18 \cdot 40$ & $18 \cdot 40$ \\
\hline
\end{tabular}

\footnotetext{
1 The sanitary services have, besides, other means of discovering tuberculous centres; the organisation of the inspection of private slaughtering places and a closer surveillance of public slaughter-houses may be specially mentioned.

2 Norway and Holland are proceeding in this manner. 
In the same way an indemnity ought not to be granted to the same proprietor more than once for all, or, at least, for a definite time to be fixed.

Lastly, we ought to turn the attention of those interested in their own protection to the system of mutual assurance against the seizure of meat.

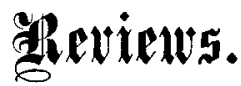

The Principles of Veterinary Surgery. By Louis A. Merillat, V.S., Professor of Veterinary Surgery in the Chicago Veterinary College. Royal 8vo, Pp. xiii. +669 , with I I 2 Illustrations. London: Ballière, Tindall \& Cox, I907.

According to the preface, in some of the veterinary schools of the United States surgery is taught during the second and third years of the curriculum. The junior student gives his attention to the essentials of surgical science and the principles of operative technique, and the senior student, while pursuing knowledge on the same lines, must acquire information concerning the symptoms, causes, pathology, and treatment of the surgical diseases. The author finds no fault with this mode of learning surgery, but, as a teacher, while acknowledging the amplitude of existing works on general and special surgery, he deplores the want of a text-book on those subjects which form the foundation of surgical knowledge, and, as an earnest of his faith, he has prepared The Principles of Veterinary Surgery, and added a translation of a small French work on surgical pathology.

The "principles" (p. 284) open with interesting chapters on regeneration and reparative processes, fever, inflammation, gangrene, thrombosis, and atrophy. Eighty-nine pages are devoted to bacteria (including those of anthrax, tetanus, tuberculosis, glanders, and black-quarter), immunity, opsonins, and sera. Surgical shock receives more consideration than it deserves, but the chapters on hæmorrhage and hæmostasis, restraint, anæsthesia, asepsis and antisepsis, and wound treatment are excellent in every way.

The second part is occupied with an annotated translation of articles on wounds, abscesses, ulcers, fistula, septicæmia, pyæmia, tetanus, actinomycosis, botryomycosis, melanosis, various tumours, and some diseases of bone by Leblanc, Cadéac, and Carougeau, professors at l,yons Veterinary School.

Though nominally a work on the principles of veterinary surgery it contains a good deal of the practice as well, and also some of the principles of pathology and veterinary medicine. Its aim appears to be too comprehensive, and, as a consequence, the contents are rather mixed. It is a far cry from bacteria and Ehrlich's side-chain theory to casting horses for operation. But, notwith. standing this fault, the book can be commended to practitioners who desire to revise their knowledge of surgical pathology. The "principles" will be helpful to students who have not the advantage of separate courses of instruction on pathology and bacteriology, medicine, and surgery; but perhaps it would be better to reorganise some of the American veterinary schools than to encourage the production of composite text-books. 